\title{
Student/teachers from Turfloop: the propagation of Black Consciousness in South African schools, 1972-76
}

\author{
Anne Heffernan
}

\section{Introduction}

On 16 June 1976, South African schoolchildren in Soweto made history when they marched against the repressive manifestations of apartheid education in their classrooms. The uprising marked a pivotal shift in anti-apartheid resistance, heralding the political rise of a new generation and changing the way in which both the state and existing liberation movements related to the youth of the 1970s. There has been substantial scholarship on this event and its historical context, from Baruch Hirson's Year of Fire, Year of Ash (2016 [1979]), written in the wake of the uprising, to recent scholarly interventions such as Julian Brown's The Road to Soweto (2016).

The literature on the Soweto Uprising points to the important role played by particular teachers in Soweto's classrooms, who encouraged political development and fomentation among their students (Brown 2016: 128-9; Magaziner 2010: 156-7; Glaser 2000: 162). Most prominent among these was Onkgopotse Tiro, a member of the South African Students' Organisation (SASO) leadership and a history and politics teacher at Morris Isaacson High School in central Jabavu, Soweto. Tiro came to teach at Morris Isaacson in the wake of being expelled from the University of the North, and his is nearly always the name that is mentioned in relation to this period of student conscientization, and the role that teachers played in it. But Tiro was only the most famous of a cohort of young university students who were expelled from the University of the North, and other black universities, for their political activism. In the wake of waves of expulsions, many of these young people sought and gained jobs in secondary schools around South Africa and in its ostensibly independent Bantustans. Their impact on the conscientization of a generation of student activists, and on the transmission of new political ideas and forms of organization, has not yet been adequately analysed and understood. This article seeks to tell the stories of three of these teachers. It argues that these figures and the ideas they propagated were made more influential by the process of moving through nodal spaces and institutions in South African townships and rural areas, and that their ideas and forms of action were fundamentally shaped by the spaces through which they moved. This movement and the networks it created were a direct result of apartheid restrictions on where black South Africans could live, study and work. This all

\footnotetext{
Anne Heffernan, at the time of writing, was a post-doctoral research fellow in the History Workshop at the University of the Witwatersrand, Johannesburg. She is now Assistant Professor of Southern African History at Durham University, UK. Her research has focused on the history of student and youth politics and education in Limpopo Province, and on Bantustan politics in northern South Africa. Email: anne.k.heffernan@durham.ac.uk
}

(C) International African Institute 2019 
came to bear in the influence of these teachers on - arguably - South Africa's most famous generation of student activists, the youth of 1976 .

I argue that the placement of these school teachers and tutors in primary and secondary schools around South Africa and its Bantustans in the early and mid-1970s was an intentional part of the project of expanding the political reach of Black Consciousness to school learners during this period, driven predominantly by SASO. The movement of these educators played a key role not just in their ability to spread a particular political philosophy (Black Consciousness), but in the political forms and methods they chose to teach this. These were shaped both by their own political conscientization and training in so-called 'bush' colleges - ethnically segregated university colleges predominantly located in rural areas - but also in large part by the political and social realities of the areas to which they moved. Their efforts not only laid the foundation for Black Consciousness organization in communities across South Africa, they also influenced student mechanisms for political action beyond the scope of Black Consciousness politics. Notably, there has been some scholarly debate over the ideological influences on these students - between the racially exclusive tenets of Black Consciousness and the multiracialism espoused by the African National Congress (ANC) and others (Diseko 1992; Ndlovu 2017). These debates are further explored in a subsequent section of this article, but for the purposes of its framing here, it is sufficient to note that, for the students of 1976, Black Consciousness was an important, but not singular or isolated, political influence.

Particularly in the context of this special issue on university student activism across Africa, it is important to also recognize the role that Pan-Africanist ideals, front-line state solidarity and anti-colonial victories elsewhere on the continent played in influencing South African students in the 1970s. One of the teacher biographies here recalls the Pan-Africanist literature - by authors and statesmen such as Kwame Nkrumah and Julius Nyerere - that was being read and circulated among politicized schoolchildren in Soweto in 1975 and 1976 (Chikane 1988: 56). Schenck (2019) discusses in this special issue the role played by the victory of FRELIMO (Frente de Libertação de Moçambique or the Mozambique Liberation Front) over the Portuguese in neighbouring Mozambique in galvanizing student protest on one South African campus. Others note the inspiration and influence that the protesting Soweto students provided for other students around the continent, highlighting the way in which the circulation of political ideas and practices - both domestic and transnational has shaped student protest across Africa.

Some scholarly attention has been given to the role of teachers in influencing the students of the Soweto Uprising (Glaser 2015), but thus far this literature has focused on these teachers in the space of the schools where they taught. How educational migration, prompted by the strictures of the apartheid state, created an entire generation of young teachers moving throughout the country has yet to be adequately explored. I situate these teachers not only in the literature on Black Consciousness and political resistance within South Africa, but as analogues to a literature on global circular migration. Drawing on the work of scholars such as AnnaLee Saxenian, I argue that, as educated circular migrants, these teachers left enduring impacts on their communities of origin, of education, and where they were educators themselves. 
As a case study, this article examines the trajectories of three teachers after their graduations (or expulsions) from the University of the North (Turfloop). They each came to Turfloop from villages and/or townships, and left it to become teachers in the Bantu Education system, operating largely in an educational world of apartheid planners' making. This pattern of movement shaped the knowledge they transmitted in their classrooms, and thus influenced the political consciousness of a new generation. This article considers the lives of teachers who worked in Soweto itself (Frank Chikane and Onkgopotse Tiro), and in the Venda Bantustan (Pandelani Nefolovhodwe), in order to make preliminary conclusions about differing organization between urban and rural areas. It is based on archival analysis and oral history research conducted between 2011 and 2016.

\section{Circulating teachers, circulating ideas}

This article situates three South African teachers in a global conversation about how physical movement affects the circulation and development of skills and ideas. It aims to understand the impact these teachers had, in part by offering a comparison with educated migrants in India, China and Silicon Valley. But it also recognizes that their stories are fundamentally South African ones. The spaces through which they moved were shaped by apartheid policies. Some were born in townships, to parents who were often economic migrants themselves, and many straddled lives in these urban centres with connections to extended family in rural villages. Some experienced interrupted, peripatetic schooling, moving between these spaces even as children. When they reached university, their choice of where to study was circumscribed by the strictures of Bantu Education. In 1959, the Extension of University Education Act brought educational segregation to the tertiary level and created 'university colleges' for separate ethnic groups. The University College of the North - Turfloop - was designated for the Sotho, Tswana, Tsonga and Venda. Students from these ethnic groups who aspired to a university degree - whether from the townships on the Rand or from villages in the countryside - had no choice but to enrol at Turfloop and move to the campus, which was located in the Northern Transvaal on the road running between the 'white' towns of Pietersburg and Tzaneen.

This attempt at ethnic homogeneity was not entirely successful; Turfloop was in fact more ethnically diverse than its fellow black universities, because it catered to several smaller ethnic groups. It was also subverted by other forms of heterogeneity in the Turfloop student body - principally geographic difference. Over the first decade of its existence (1960-69), Turfloop went from having a majority ruralorigin student body to a majority urban-origin one, although, as White has noted, many students had a foot in both of these worlds (1997: 83). This coincided with increased politicization among the student body - the decade on campus was marked by a (successful) move to implement a democratic Student Representative Council, an unsuccessful attempt to affiliate to the multiracial National Union of South African Students (NUSAS), and the rise of new political student organizations, particularly the University Christian Movement in 1967 and SASO in 1969 (Heffernan 2014). The latter will be the subject of the next section.

But first, beyond their movement through the black-designated spaces of segregated South Africa, I propose thinking of these teachers in relation to a more 
global literature on migration - particularly in relation to literature on brain drain and brain circulation. This illuminates their position and influence as educated migrants who helped circulate skills and ideas (in this case, especially political ones) that were developed in the educational institutions of the Bantu Education system.

Brain drain is the supposition that educational and skilled migration from underdeveloped areas, regions and countries to more developed ones exacerbates developmental inequality between these places. It hinges on a core-periphery understanding of development, in which the core is the developed centre (a migratory destination), and the periphery is the conglomeration of less developed places of migratory origin (Todaro 1977: 261). Saxenian has challenged this model in her work on the relationship between Silicon Valley in the United States and communities of origin, in both China and India, of software developers who were educated and/or worked in Silicon Valley (Saxenian 2005; 2006). She offers a corrective to the literature on brain drain, which she argues fails to 'anticipate the development of independent technological capabilities in the periphery' that results in part from the influence of educated migrants who come from peripheral communities (Saxenian 2005: 37). Saxenian instead suggests a new model - of brain circulation - to better account for the mobility of highly skilled and educated workers and information, and the rise of communities of technically skilled immigrants with connections to Silicon Valley back in their countries and regions of origin (ibid.: 39). Brain circulation promotes development in regional centres because "[t]he ease of communication and information exchange within ethnic professional networks accelerates learning about new sources of skill, technology, and capital, as well as potential collaborators' (ibid.: 38). Relatedly, Xiang Biao has written of the rise of the practice of transnational 'body shopping', whereby Indian consultancy firms supply IT workers on a contract basis to employers all over the world, resulting in the creation of new networks between these highly mobile (and precarious) workers and their families and communities of origin (Biao 2007). Like Biao's IT workers, the Turfloop teachers moved through a system (created by the Bantu Education Department, and apartheid more broadly) that demanded their employment but that was fundamentally precarious for them. It inculcated a high degree of mobility in these teachers, which in turn fostered new political networks across educational institutions.

Both Saxenian's software developers and Biao's IT workers differ from the teachers considered here in important ways. They are people moving within transnational systems, which, as Biao notes, are substantially freed from 'the primary institution managing public life: the nation-state' (Biao 2007: 2). In stark contrast, the teachers from Turfloop operated in a world fundamentally shaped by the apartheid state - and intensely monitored and controlled by it. The factors influencing their movements were as much political as economic. Extrapolating Saxenian's argument to schoolteachers in 1970s South Africa though not a perfect parallel - enables us to think about these young people who were expelled from Turfloop as part of a skilled labour force in a market with high demand for their skills (Glaser 2000: 129; Hyslop 1989; 1999). ${ }^{1}$ Their

\footnotetext{
${ }^{1}$ Glaser notes that, under pressure from the manufacturing sector over a shortage of skilled labour in the early 1970s, Vorster's government permitted the expansion of urban black schools to support the development of this new workforce (2000: 129). This ought not to be taken as a deep ideological change so much as a pragmatic shifting of course. Hyslop argues that the
} 
connections to both ethnic and geographical networks enabled them to move and promote new forms of political ideas and action between different educational spaces, resulting in the growth of political consciousness across these various nodes. In this analogy, teachers and students are the software engineers, Turfloop is Silicon Valley, and the secondary schools of South Africa's townships and villages are the 'peripheral' regional centres whose (political) development accelerates and - in this case - overtakes that of the core.

\section{Ideology and Black Consciousness in SASO}

The South African Students' Organisation (SASO) was conceived by a cohort of black university students in 1968. They were responding to the alienation they experienced in the existing NUSAS, which was multiracial but predominantly white - and although it expressed radical anti-apartheid politics, it was dominated by the concerns of its white constituents. The following year, in early 1969, the new black student organization was launched on the campus of the University College of the North. The university, colloquially called Turfloop after the farm on which it had been built, was designed to educate black students and was located in the northern Transvaal, isolated from major urban centres.

SASO was the brainchild of a new generation of student activists in South Africa. By 1968 the country's most prominent liberation movements - the ANC and Pan-Africanist Congress (PAC) - had been banned for eight years. The intervening period has sometimes been described as politically quiescent, though new scholarship points to forms of organization during the mid-1960s when resistance in South Africa was purportedly moribund (Brown 2016: 21; Murphy 2012). In looking back on the trajectory of South African history and anti-apartheid struggle, the formation and organization of SASO has often been seen as having bridged the period in which these liberation organizations led mass-mobilized protest in the 1950s and early 1960s, and the later broad-based resistance to apartheid that emerged in the wake of the 1976 student uprising. But as Magaziner (2010: 6) argues, SASO took a different approach to politics to that of the more formally constituted liberation organizations, and a teleological approach to this history runs the risk of flattening the history of SASO - and its Black Consciousness ideas - into that of a cog in the machine of anti-apartheid resistance that rolled inexorably towards 1994. Instead, Magaziner considers the history of SASO an intellectual one - the history 'of both thinkers and their ideas' (ibid.: 6).

Those ideas differed from those of their predecessors in organizations such as the ANC and PAC in important ways. Firstly, SASO sought to make a new world - one that eliminated the privilege of whites over blacks, and that restored the dignity of the black man. ${ }^{2}$ The elimination of apartheid was a necessity in this project, but it was not its ultimate goal. This was complete liberation - not just from the overt structures of apartheid, but from its roots (racist white domination)

establishment of Bantu Education itself was primarily about the reproduction and stabilization of the urban wage-labour force, couched in racist ideology (1989).

${ }^{2}$ Despite the intentional use of 'man', gender was a contested space within Black Consciousness politics, and as Magaziner notes, 'some women [in the movement] articulated limited but potent feminist-inspired demands' (2010: 7). 
and its effects (black psychological subjugation). According to Biko, writing in September 1970:

A number of organizations now currently 'fighting against apartheid' are working on an oversimplified premise. They have taken a brief look at what is, and have diagnosed the problem incorrectly. They have almost completely forgotten about the side effects and have not even considered the root cause. Hence whatever is improvised as a remedy will hardly cure the condition. (Biko 2017: 29)

This cure necessitated psychological liberation of South African blacks from the shackles of inferiority that both apartheid and colonialism had enforced upon them. SASO saw this psychological freedom as a first and critical step before physical freedom could be achieved.

Black Consciousness differed as a political project from other liberation movements, and sometimes came into ideological conflict with them. One of its core tenets - a broad concept of black identity that included black Africans, Indians and coloured people; effectively all of the races that had been subjugated under apartheid - set it immediately apart from the multiracial cooperation that the ANC espoused (often referred to as 'Charterism' for its roots in the 1955 Freedom Charter), or from the narrower definition of 'black' understood by the Africanist PAC. The battle for political primacy between these ideologies was one of the key features of the mid- to late apartheid years. During the early 1970s, when both the ANC and PAC had long been banned and the new philosophy of Black Consciousness emerged on university campuses, it made swift headway, becoming a national movement and galvanizing a great deal of support, particularly among students. But by the 1980s, after harsh state repression against Black Consciousness organizations and a successful return to above-ground organizing by the ANC through proxies including the United Democratic Front (UDF), Charterism was in the ascendancy once more. I have argued elsewhere that, during the 1980s and early 1990s, the ANC 'achieved hegemony by absorbing opposing ideologies, particularly aspects of Black Consciousness and Africanism, into the fold of its nonracialism' (Heffernan 2016: 665). ${ }^{3}$ The ANC's success in this regard has a great deal to tell us about its political dominance in the post-apartheid era, and the concomitant marginalization of competing racialized political ideas such as Black Consciousness.

As a fundamentally intellectual project, SASO and Black Consciousness flourished at black universities - the very institutions that the apartheid government had established to train civil servants and the professional classes of its Bantustans - but it struggled to gain a foothold in the world of more formal liberation politics despite SASO activists' attempt to organize a broader public through the Black People's Convention (BPC). However, it found fertile ground among a new generation of students, bringing its intellectual message of

\footnotetext{
${ }^{3}$ Multiracialism and nonracialism, in the context of the ANC, both describe its policy of including many different racial groups in the struggle for liberation - first as allies through their own racially based congresses, and later in the membership of the ANC itself. For more on this and on the ANC's own shifting definitions of these terms, see Frederikse (1990) and Everatt (2010). Black Consciousness also espoused its own version of nonracialism, which it used to describe the inclusivity of its idea of blackness.
} 
psychological liberation and black dignity into secondary schools around the country. As I discussed in the introduction, this was accomplished in large part through the work of teachers who had themselves been student activists at universities such as Turfloop, Fort Hare and Zululand. Many were expelled as a result of their activism and ties to SASO, and many of those took teaching jobs in both townships and rural areas. ${ }^{4}$

Once they arrived in secondary schools, SASO activists found that a framework for political organization was already established within some schools. The African Students' Movement (ASM) had emerged in the late 1960s at Diepkloof High School in Soweto. It spread to a limited number of neighbouring schools, first Orlando West High School and Orlando High School, and drew together students primarily from Christian youth groups such as Y-Teens, Leseding and Youth Alive (Diseko 1992: 43). Furthering this Christian identity, the ASM in its early days had links to the University Christian Movement (UCM). UCM members such as Tom Manthata, then a teacher at Sekano Ntoane High School in Soweto, encouraged the fledgling group and provided them with 'access to literature on developments in Africa' (ibid.: 43). ASM's political development focused on Africanism in its early years (thanks in part to literature from people such as Manthata). The first organizing secretary of SASM - the South African Students' Movement, ASM's successor - described that ideological formation: 'We were grappling and experimenting with Africanism and did this on our own, without reference to the PAC ... We were just trying for ourselves to work out what it means to be African' (ibid.: 43).

They also grappled with national identity: by the early 1970s, the ASM had come to focus on the political situation inside South Africa, and this was reflected in its 1972 change of name to the South African Students' Movement, which coincided with the efforts of SASO to conscientize school students. Tebello Motapanyane, one of the key leaders of the June 1976 uprising, described this shift as reflective of the organization's national growth: 'By 1972 it was decided that since the movement was now national, it should be known as the South African Students' Movement, that is SASM' (Motapanyane 1977).

Glaser argues that the name change from ASM to SASM also represents a growing identification with SASO, and its 'more inclusive interpretation of black identity' (2000: 162). There is some scholarly debate over the ideas and contingencies that influenced the students who participated in the Soweto Uprising. The majority of authors on the subject, including Glaser (2000), Badat (1999), Mkhabela (2001), Brown (2016), Hirson (2016 [1979]), Magaziner (2010) and Nieftagodien (2015), have emphasized the importance of Black Consciousness ideology in conscientizing the students of 1976. Even Nozipho Diseko, who

\footnotetext{
${ }^{4}$ It is hard to put definitive numbers on these teachers - as the case studies in this article demonstrate, some were only briefly employed at schools, and some worked informally as tutors organized through community networks in the face of an overextended educational system. As far as I have been able to ascertain, from Turfloop there were at least ten such people (and likely more) who became teachers in the wake of the university's May 1972 closure, and as many again after the wave of expulsions in September 1974. Anecdotal accounts from other university colleges suggest that this pattern was replicated elsewhere at different moments, but further research on places such as the universities of Zululand, Fort Hare and the Western Cape is called for to corroborate and analyse this.
} 
offers a corrective to the dominance of this narrative and argues for the impact of ANC underground structures on some Soweto student leaders, acknowledges the role that Black Consciousness played in politicizing this generation of activists (Diseko 1992: 57). Diseko is part of a body of scholars, however, who argue that the existing literature overstates the importance of Black Consciousness as an ideological influence on the schoolchildren of the 1970s. Sifiso M. Ndlovu (2017) contends that Soweto schoolchildren were driven principally by the implementation of Afrikaans as a teaching medium and suggests that an overemphasis on Black Consciousness neglects local contingencies at the school level that influenced students' turn to activism. There is ample evidence to support the argument that students had differing affiliations across the liberation groups that were operating in the country during the early 1970 s, and that some had no direct affiliation. Sibongile Mkhabela, a student at Naledi High School and the general secretary of SASM in 1976, recalled ideological diversity in SASM's ranks by the middle of the decade:

Within SASM there were people who had sympathies for ANC, sympathies for PAC, and all sorts of other sympathies. We'd debate and fight over this, but there would be some consensus. We agreed on certain basic principles ... For me it was a strength ... within SASM - If you look at Murphy Morobe, he's always been an ANC kind of person. I've always been a BC [Black Consciousness] kind of person. ${ }^{5}$

The ASM became SASM, laying the groundwork for student organization in schools, just as political protest was beginning to heat up on black university campuses. Onkgopotse Tiro's high-profile expulsion in 1972 and the subsequent protests at Turfloop, Ngoye, Fort Hare and others were the first public signs of major dissatisfaction at the 'bush' colleges. These developments had important implications for the growing politicization among school students across the political divide, especially by creating a new cohort of teachers who had been conscientized in Black Consciousness and expelled from university.

This article makes an argument about the impact of Black Consciousnessaffiliated teachers in South African schools, in Soweto and elsewhere, but it does not presume to suggest that theirs was the only influence on the students of 1976. Sekibakiba Lekgoathi $(2016 ; 2017)$ argues persuasively that Black Consciousness was less immediately impactful in schools in South Africa's rural north than it was in urban townships, an argument that is supported by one of the case studies that follows and by the work of Tshepo Moloi (2015) and Peter Delius (1996). Youth in these areas became more politically active in the late 1970s and 1980s. But Lekgoathi also acknowledges the role that Black Consciousness played in the region, through the vehicle of Turfloop: 'Being one of the most politicized black universities in the country, as well as the bedrock of the Black Consciousness ideology, the University of the North [Turfloop] influenced political developments in the schools and teacher training colleges of the region' (Lekgoathi 2016: 111). The influence of the University of the North

\footnotetext{
${ }^{5}$ Interview with Sibongile Mkhabela, conducted by the third-year class of African politics students at the University of the Witwatersrand, Johannesburg, 13 August 1994, Historical Papers Research Archive (HPRA) A2675/I/23.
} 
to which Lekgoathi refers, and particularly of some of its Black Consciousnessleaning students, is the crux of this article and is elaborated in the following sections.

\section{The teachers and the ideas they carried with them}

\section{Onkgopotse Tiro 6}

Onkgopotse Tiro, the most famous student to be expelled from Turfloop in the early 1970s, was born near the Botswana border in 1945. He grew up in the village of Dinokana, outside Zeerust, in the rural area of Lehurutshe. Like rural communities in Pondoland and Sekhukhuneland in the late 1950s, Lehurutshe erupted in a rural rebellion (the Hurutshe Revolt) against the imposition of the Bantu Authorities Act - which led to the deposition and exile of local chief Abram Moiloa - and the requirement that women begin to carry passbooks (Lissoni 2016: 35-6). A period of protracted violent resistance from 1957 to 1959 disrupted Tiro's primary schooling, but also had a profound impact on the development of his political consciousness and that of other youths in the area, as Lissoni has demonstrated (ibid.: 36). It also prompted Tiro's first move away from home - initially to work as a dishwasher on a nearby manganese mine, and eventually to enrol in Naledi High School, in Soweto, where his mother, a domestic worker in Johannesburg, was residing. But under apartheid law, Tiro's birth in Dinokana did not permit him to attend school in Soweto; a pass-law violation sent him back to what was then the Western Transvaal after only a few months. He enrolled in and completed secondary school at Barolong High School in Mafikeng, where he soon made a name for himself as a principled and powerful orator (Heffernan 2015: 175).

In 1968, Tiro enrolled at the only institution of tertiary education available to him as a person from a SeTswana background: Turfloop. Later that year, SASO was founded at the University of Natal-Black Section, and in early 1969 it was formally launched at Turfloop. At the time, Tiro was gaining notoriety as a student leader on campus, and in 1971 he became president of the Student Representative Council (SRC), which had closely associated itself to SASO and Black Consciousness ideas. But Tiro's fame extended beyond Turfloop for the first time in April 1972, when he gave an inflammatory speech at that year's graduation ceremony.

He had been nominated to speak by the current SRC, headed by his former deputy, Aubrey Mokoena. Although most graduation speakers lauded Turfloop a Bantustan university - and the broader policies of 'separate development', Tiro broke with this mould (Butler 2007: 48). He criticized the very premise of segregated education head-on. He attacked its hypocrisy at Turfloop - for putting white bureaucrats in charge of a black university - and declared that guilt for the 'repugnant' system rested with everyone who failed to work for its eradication (Tiro 1972). In response to this overt criticism and challenge, the (all-white) council of the University of the North voted to expel Tiro. Their decision

\footnotetext{
${ }^{6}$ Some of this brief biographical sketch draws on material from Heffernan (2015), which contains a fuller account of Tiro's biography and his role in developing Black Consciousness ideas.
} 
prompted a series of events that would shape protest and resistance at the university in the years to come: black academic staff (who had not been allowed to vote on the expulsion) broke with their white counterparts and formed a separate Black Academic Staff Association; the student body, led by the pro-SASO SRC, called for a class boycott until Tiro was reinstated; the university, in response to the boycott, closed the campus and terminated all students' registrations. While protesting Turfloop students went home to townships and villages around South Africa, students at other black universities staged solidarity strikes, solidifying SASO's national organization (Massey 2010: 212-15; Heffernan 2014: 67-8).

Meanwhile, Tiro also went home - initially to Lehurutshe, where, as Lissoni has noted, he embarked on a tour of schools, talking about his expulsion and propagating Black Consciousness ideas. As one student in a Dinokana middle school recalled:

He gave us a good political lecture and told us why he was there, why he was expelled and why we must stick to education irrespective [of the injustice of the system of Bantu Education] and he narrated the whole situation about how black people are being treated ... the kind of environment that the black students find themselves in, and what is it that we need to do in order to undo that system. Now that is the education and the lecture that stayed in my mind forever, and in any interview about my life ... I mention this because it is actually the [turning] point. (Dikang Uhuru Moiloa quoted in Lissoni 2016: 39-40)

After visiting several schools in the Lehurutshe area, and inspiring students who went on to Turfloop to become involved in Umkhonto we Sizwe and to be teachers themselves (Lissoni 2016: 37-42), Tiro moved once more to Soweto. In spite of his expulsion from Turfloop, he had a bachelor's degree and partially completed university diploma in education; in 1972, when townships faced booming numbers in their enrolment of schoolchildren and inadequate resources and staff to teach them, Tiro's political past did not preclude his employment. The principal at Morris Isaacson High School, Lekgau Mathabathe, hired him to teach English and history.

His experience was not unique. Teaching became an outlet for many politically active university students who were expelled in waves of protest at places such as Turfloop between 1972 and 1974. In his testimony after the Soweto Uprising, Aubrey Mokoena, former Turfloop student and president of the SRC, noted that 'BPC and SASO had some of its members teaching in schools ... It was the duty of these people to conscientise students with regard to the struggle for liberation. ${ }^{77}$ Among these teachers, Mokoena noted Tiro at Morris Isaacson, himself at Orlando North Secondary, Tom Manthata at Sekano Ntoane High School, and Cyril Ramaphosa and Lybon Mabasa at Meadowlands High School. All of these, except Manthata, had been students at Turfloop and were expelled for their political activities.

Their work was effective, because by 1973 SASM had established a cooperative relationship with SASO, and was using the language of Black Consciousness.

\footnotetext{
${ }^{7}$ 'Deposition of Aubrey Mokoena taken by Justice of the Peace D. L. Aspelling in Johannesburg', undated (c. early 1977), HPRA A2953.
} 
Nozipho Diseko has argued persuasively, to counter the way in which much of the literature has conflated these two movements, that SASM did not develop as a school wing of SASO, and that in fact it predated the development of Black Consciousness as an ideology (Diseko 1992). Although SASM did not develop as a subset of SASO and had its own autonomous identity, there is evidence that development within the two organizations converged in the early 1970s. Teachers from the Black Consciousness Movement (BCM) who were teaching in schools with SASM branches fostered this ideological symmetry. Tiro, in his role at Morris Isaacson, was perhaps the closest SASO member to the workings of SASM. He acted as liaison between the organizations, and under his watch an official wing of SASM was created for SASO and older members; from the SASO perspective, there was SASM (Junior), which was the original South African Students' Movement, based in schools, and SASM (Senior) which consisted of affiliated groups such as SASO that supported SASM's efforts to conscientize and organize school students. Tiro became the first president of SASM (Senior), ${ }^{8}$ a semi-formalized position that was designed to facilitate cooperation between SASM and other organizations in the BCM, including SASO and the BPC.

As a teacher and in his capacity as SASM liaison, Tiro worked to seek out politically curious and motivated students and strove to conscientize them in the SASO mould. The students who passed through Tiro's classes, and whom he took under his wing, were to become some of the most prominent figures in the next generation of student political actors. One, Tsietsi Mashinini, later became the chair of the influential Soweto Students' Representative Council (SSRC), which played a critical organizational role in the June 1976 Soweto riots and their aftermath. Another of Tiro's students was Esau Tshehlo Mokhethi. Older than Mashinini, he had already moved to Turfloop by 1976, where he was involved in the reorganization of the SRC at the university, and later became an activist in the Azanian People's Organization (AZAPO) (Dikobo 2012). Such direct links to students such as Mashinini and Mokhethi are evidence of how, in a short time, Tiro's political influence had been expanded as a result of his work at Morris Isaacson.

As significant as this influence was, it was short-lived in terms of direct studentteacher contact. Glaser has noted that: 'The [Department of Bantu Education] forced some of these teachers out of their Soweto jobs, but they were often able to make a major impact even in the few weeks or months of their stay' (Glaser 2000: 162). Tiro was dismissed from Morris Isaacson less than a year after he had started. As the Rand Daily Mail reported: 'In February [1973], after months of confrontation between the local school committee and officials of the Bantu Education Department, Mr. Tiro was sacked from his teaching position at Morris Isaacson High School in Soweto.' ${ }^{9}$ The timing of his dismissal coincided with a nationwide crackdown on SASO and BPC activists: in early March 1973

\footnotetext{
${ }^{8}$ 'Composite executive report to the 6th GSC', 7 July 1974, p. 2, HPRA A2176; 'Deposition of Aubrey Mokoena taken by Justice of the Peace D. L. Aspelling in Johannesburg', undated (c. early 1977), p. 20, HPRA A2953; T. Mashinini, 'Behind the growing upsurge in South Africa', Intercontinental Press, 15 November 1976, HPRA A2953.

'Bomb kills ex-Saso leader', Rand Daily Mail, 4 February 1974, HPRA AD1912/239.
} 
banning orders were issued against the most prominent leaders in both groups, including some of SASO's top leadership. Tiro joined a group of these activists and went into exile in September 1973.

These activists remained active in their efforts to bolster student resistance within South Africa, and to raise support for their cause within Botswana and beyond. Tiro had papers allowing him to move legally between South Africa and Botswana, so he assumed the role of SASO's permanent organizer. He got another teaching job, this time in Gaborone, but also continued to travel and speak to students in South Africa and Lesotho. Tiro had little time to pursue this work, however. Five months after leaving South Africa, on 1 February 1974, he was killed by a parcel bomb. The package was addressed from a European educational fund, but was delivered by hand to Tiro in Gaborone and was probably sent by agents of the South African state.

The public reaction following Tiro's death speaks to the impact of his activism, particularly in spreading Black Consciousness ideas among a new generation of students. In a memorial to him at the General Students Council that year, SASO said: 'Circumstances surrounding Tiro's death have [not] been made absolutely clear, but one thing [is] certain, he died at the violent hands of agents of imperialism. ${ }^{10}$ When the news reached SASO's branches in the Transvaal, 'Members from all [sic] over the region started flooding into the office and became involved in several undertakings that were geared at the burial of our brother. Fundraising lists were prepared and widely distributed around the regions. ${ }^{11}$ Memorials for Tiro were held at Regina Mundi Catholic Church in Soweto, one of the township's largest churches, as well as in Kimberley and at Turfloop itself. Students from SASO and its affiliates raised more than R2,000 in support of a memorial held in Tiro's home village of Dinokana, and many, including those in the acting executive, travelled to the remote area of the north-western Transvaal to attend. ${ }^{12}$ Meanwhile, more than 1,200 people attended a special ceremony in Tiro's memory at the Roman Catholic cathedral in Gaborone, Botswana. ${ }^{13}$

The loss of Tiro was a blow to SASO, as well as to Turfloop and the school students for whom he had been a formative figure in their political education; but rather than dampening student activism for his cause, his death furthered the resolve of the organizations with which he had worked. As the SASO Transvaal regional secretary at the time noted: 'The enemy must have really joyfully felicitated for the brutal and cold-blooded murder, though at least realising that on that very point in time a hundred Tiros emerged and decided to join hands with those who are involved in the fighting against oppression. ${ }^{14}$

\section{Pandelani Nefolovhodwe}

The urban areas of the Rand attracted a large number of expelled Turfloop students, many of whom became teachers, due to the expansion of township schooling, but also because many had personal or familial links to the townships outside

\footnotetext{
${ }^{10}$ 'Composite executive report to the 6th GSC', 7 July 1974, p. 2, HPRA A2176.

11 'Transvaal region report to the 6th GSC', pp. 1-2, HPRA A2176/5.5.

${ }^{12}$ Ibid., p. 2.

13،1200 Mourn Tiro', The Star's Africa News Service, 9 February 1974, HPRA AD1912/239.

14، Transvaal region report to the 6th GSC', p. 1, HPRA A2176/5.5.
} 
Pretoria and Johannesburg. Although Soweto was a hotspot for such activism, it existed elsewhere as well. Students circulated through rural networks as well as urban ones. Pandelani Nefolovhodwe, a member of the SRC committee that had invited Tiro to speak at the 1972 graduation, also found employment as a teacher, in Thohoyandou, Venda in $1973 .{ }^{15}$

Nefolovhodwe grew up in the far northern village of Folovhodwe, about 70 kilometres south-east of the border town of Musina, and approximately 30 kilometres south of the great Limpopo River, which marks South Africa's northern border. The local school reached only Standard 2, so at approximately the age of ten 'Nef' moved to a new primary school, about 40 kilometres away from home. In Standard 5, around 1963, he moved again, this time to Mphaphuli High School, a joint junior/secondary and matric school, in the Venda Bantustan capital of Thohoyandou. After two years he won a bursary that required him to move once more, this time to Vendaland Training Institute (today Tshisimani College) in Tshakhuma, outside Thohoyandou. ${ }^{16}$ By the time Nefolovhodwe enrolled at Turfloop in 1969, he had spent half of his life moving from school to school, across the villages and towns of South Africa's far north.

In his first year at university Nefolovhodwe registered to study science - specializing in zoology and botany - but the launch of SASO on campus and the progressive SRC under the leadership of Petrus Machaka quickly inspired him to become politically active. In 1971 he became the publicity secretary of the SRC, which that year was led by Onkgopotse Tiro. As a member of the 1972 SRC that invited Tiro to give his controversial graduation speech, Nefolovhodwe was one of a number of students (including Tiro and the entire SRC) who were expelled and banned from re-registering for a period of two years, in June 1972. During that period he took a job as welfare officer at a mine near Musina, and then was recruited to teach science and maths at his old secondary school - Mphaphuli High - in Thohoyandou, which he began in early 1973.

Even though he was teaching maths and science, Nefolovhodwe strove to conscientize his students politically. He instituted a weekly current affairs lesson for his senior students: 'I was worrying about these ones who may finish schools and go to universities, so I was trying to link them with the activities already at a higher level. So that is what I used to do, and it went very, very well.' ${ }^{17}$ With the cooperation of a sympathetic principal, Nefolovhodwe structured his weekly lessons to allow time on a Friday afternoon to discuss current affairs.

I would request them to read all the newspapers, the ones that were around that area there were only two or three types of newspapers - during the course of the week, my science students ... So on Fridays the students they take over - they tell me about what is happening around the area, around the country; just [to] broaden their scope about what is happening. And once we finish I would say, 'What have you seen or read that makes you believe you can use your science and mathematics for the good of society?' That's the first thing, and that's more relevant to their studies. But I would

\footnotetext{
${ }^{15}$ Author interview with Pandelani Nefolovhodwe, Germiston, 27 September 2011; 'SASO 9 trial transcript', p. 5561 (Nefolovhodwe), HPRA AD2021/14.1.

${ }^{16}$ Author interview with Pandelani Nefolovhodwe, Germiston, 27 September 2011.

${ }^{17}$ Ibid.
} 
add my own political activism; that's what I used to do. But the first thing to do was to make them understand that all science is meant to resolve societal problems. ${ }^{18}$

Nefolovhodwe understood himself to be part of a larger network of teacher activists, predominantly coming out of SASO, undertaking this work. 'A lot of expelled students went to teach at schools ... They went to continue with the activities of informing the younger generation about this - we used to call it a system the apartheid government. ${ }^{19}$

In 1974, Nefolovhodwe once again left Mphaphuli High School, to return to Turfloop. He re-enrolled to complete his BSc degree, which had been left unfinished after his expulsion two years earlier. He also picked up his campus activism once more. Although SASO had been banned on campus in the wake of the 1972 closure of the university, it retained support among the student body, and Nefolovhodwe, along with a younger cohort of students who had been spared expulsion in 1972, proceeded to found an off-campus branch with the help of SASO executive member and Turfloop alumnus Mosiua (nicknamed Terror) Lekota. ${ }^{20}$ In March 1974, Nefolovhodwe became the chair of the new off-campus SASO branch, based in nearby Mankweng. Over the next few months he also became the president of the Turfloop SRC - after a vote of no confidence in the sitting SRC under Isaac Nkwe - and the national president of SASO, so that by July 1974 Nefolovhodwe occupied all three executive posts simultaneously, reinforcing the power of SASO in campus politics even as it remained formally banned. ${ }^{21}$ By September this power had been disaggregated; Nefolovhodwe remained the national president of SASO, while Cyril Ramaphosa became president of the Mankweng branch, and Gilbert Sedibe became SRC president.

All three of these figures played key roles in staging a 'Viva FRELIMO' rally, to celebrate Mozambique's independence, at Turfloop on 25 September 1974 (for more on this rally see Brown 2016: 146-9). The event resulted in violent clashes with the police, and the arrest and trial of much of SASO (and its sister BPC) in the highly publicized treason trial of the 'SASO Nine'. Nefolovhodwe and Sedibe were both among the defendants and were convicted of trying to overthrow the state, resulting in their imprisonment on Robben Island. ${ }^{22}$ The 'Viva FRELIMO' rally also resulted in another university closure at Turfloop and a round of expulsions, creating a new cohort of migrant teachers.

\section{Frank Chikane}

Frank Chikane was slightly younger than Tiro and Nefolovhodwe, and arrived at Turfloop a few years after them. He began his studies there just months before Tiro's explosive speech that resulted in the closure of the university. He arrived on campus in early 1972 after spending his childhood and adolescence in Soweto schools, culminating in studies at Naledi High School and then matriculating from Orlando High School (Chikane 1988: 34-5). Although he had not

\footnotetext{
${ }^{18}$ Ibid.

${ }^{19}$ Ibid.

${ }^{20}$ 'SASO 9 trial transcript', pp. 191-2 (testimony of Jonas Ledwaba), HPRA AD2021/14.1.

${ }^{21}$ Ibid., pp. 192-3.

${ }^{22}$ Ibid. (judgment).
} 
been involved in formal politics at the school level, Chikane had a background in leadership and organization through his involvement with the Students' Christian Movement (SCM). In 1971, when Christian students clashed violently with more political factions at Orlando High School, Chikane was asked to mediate between the groups at a mass meeting. He was successful by turning the light of Christianity on the ugly reality of life in apartheid South Africa, engaging the core concerns of both sides. He acknowledged that Christianity was 'being used to dispossess us of our land', and he exhorted students on both sides of the divide to reclaim the religion for themselves, telling them to 'Reread the Bible and reinterpret it in the light of truth, and turn it against the oppressor' (ibid.: 48).

When Chikane arrived at Turfloop, he and other new students who had been involved in the SCM at school level found the organization widely reviled on the politicized campus (Chikane 1988: 48; Butler 2007: 50-1). SASO was firmly established as the dominant student organization, and its close links to the UCM had sidelined adherents of the SCM, who had typically been more conservative than their UCM counterparts. But by 1972 UCM was banned from operating on campus, and Chikane and other members of his cohort - including Cyril Ramaphosa, Ishmael Mkhabela and Lybon Mabasa - recognized the role that a socially and politically engaged Christian union could play in student life. They set about revising the SCM's reputation on campus, getting elected to its leadership, rejecting racism and apartheid 'on doctrinal basis', and engaging with social justice issues (Chikane 1988: 49). ${ }^{23}$

These students remained engaged in campus politics over the coming years. While Ramaphosa took over from Nefolovhodwe as SASO branch chair in mid-1974, Chikane stayed in the SCM, becoming chair in 1973-74. Near the end of Chikane's final year studying applied maths and physics, in September 1974, Turfloop erupted in conflict with the police after the 'Viva FRELIMO' rally. As I have discussed above, this resulted in widespread arrests among the SASO leadership (including Nefolovhodwe) and of the Turfloop SRC. Chikane, through his prominence in the SCM, came to fill the breach:

[W]ith most of the [SRC] members in detention, or on the run, or in exile, I participated in the leadership of the student body when I was elected to head a Students' Legal Aid Fund with Ishmael Mkhabela and Griffiths Zabala as joint trustees. We took responsibility for the welfare of the detained students, their families, and that of the student body. (Chikane 1988: 35-6)

This new role thrust Chikane into a more overtly political position, and prompted him to travel regularly between campus and Johannesburg, as he sought to arrange lawyers for detained students and to liaise with their families (Chikane 1988: 36). He built networks in the Black Consciousness community, and engaged in outreach at schools on his travels. His wife Kagiso, then a senior student at Morris Isaacson High School, remembers first encountering him as an invited speaker at Naledi High, and later on a school trip to Turfloop (ibid.: 16-17). He also began to speak at university events off-campus, addressing a SASO intervarsity event in Lesotho on the subject of Black Consciousness and

\footnotetext{
${ }^{23}$ Author interview with Sydney Seolonyanne, Parktown, Johannesburg, 24 November 2011.
} 
Christianity, ${ }^{24}$ and going on evangelistic missions for the SCM as far afield as the University of Zululand (ibid.: 51).

In 1975, Chikane was nominated as the only student to give evidence, on behalf of the student body, to the Snyman Commission of Inquiry, which was tasked with determining the cause of the unrest at Turfloop during the 'Viva FRELIMO' rally. In light of his increasingly high profile as a student leader, Chikane was not allowed to return to campus to sit his final examinations, and his time at Turfloop ended without a degree. But, like Tiro and Nefolovhodwe before him, he discovered that his skills were nevertheless needed in the community.

Sibongile Mkhabela, who later became the general secretary of SASM, was a student at Naledi High (one of Chikane's former schools) in Soweto in 1975. She recalls the difficulty students faced in trying to learn subjects such as biology and maths in Afrikaans. (This issue would become the tipping point that ignited the Soweto Uprising, of which Mkhabela was a prominent leader.) Mkhabela remembers her classmates assembling a delegation to approach Chikane and ask him to assist them with private tutoring in mathematics:

The students did not think they stood a chance. Isaac Motaung, who led the delegation, could not believe the response; they had gone to Frank with little hope. However, Frank Chikane, Jacky Msimango, and Moss Makgotlhe, among other volunteers, worked with the students right through the holidays. They ensured that the students completed the entire syllabus for that year. (Mkhabela 2001: 30-1)

Mkhabela's memory of the work that Chikane and others did in helping the students of Naledi prepare for their maths and biology exams might not seem political at first glance, but the imposition of Afrikaans-medium teaching - which made the exams almost unpassable without such assistance - became the rallying cry for their generation of students, and marks this work as fundamental in the students' battle against Bantu Education.

Chikane himself recalls the months that he taught at Naledi as his first exposure to the students who would become the leaders of 1976, including Khotso Seatlholo, who was in Chikane's Form 4A class and later followed Tsietsi Mashinini (who had been Tiro's student) as the head of the Soweto Students' Representative Council. 'By being involved, in these few months, in both the SCM and the debating society, I learnt of the qualities of such students; they showed a high level of political consciousness, quoting widely from Kwame Nkrumah, Julius Nyerere, and others' (Chikane 1988: 56). Chikane's recollection indicates the importance of these spaces - outside the formal classroom - for political exchange, and that conscientization was a collaborative process between generations.

\section{Conclusion}

Through the stories of Tiro, Nefolovhodwe and Chikane I have charted three different trajectories of young teachers who brought their own political consciousness to their work among school students in Soweto, Bophutatswana and

\footnotetext{
${ }^{24}$ 'SASO 9 trial transcript', pp. 8352-3 (testimony of Frank Chikane), HPRA AD2021/14.1.
} 
Venda. Their efforts contributed to the political conscientization and organization of the 1976 generation, and in the cases of Tiro and Chikane, directly influenced some of the key leaders of the Soweto Uprising.

After their work in schools, Turfloop's activist teachers discussed here followed various paths. Tiro's life as a SASO/BCM organizer was cut short by a parcel bomb in Botswana in early 1974; he never lived to see his former students take to the streets of Soweto.

Frank Chikane has remained a public figure, ascending through his involvement in both political activism and Christian organizing to become secretary general of the powerful South African Council of Churches in 1987, a post he held until 1994. During Nelson Mandela's presidency he became, and has remained, a member of the ANC's National Executive Committee. He was especially prominent in the wake of the removal of president Thabo Mbeki from office in 2008, and he wrote a book about those events (Chikane 2012).

In June 1976, by the time the Soweto Uprising erupted, Nefolovhodwe and his fellow accused - the 'SASO Nine' - were on trial for treason. After his release from Robben Island in the 1980s he returned to political organization - first through a Black Consciousness-aligned mining trade union (the Black Allied Mining and Construction Workers Union) and then later through the formal political party of AZAPO. He served as AZAPO's only member of parliament from 2001 to $2009 . .^{25}$

Notably, Nefolovhodwe is the only one of these activists (excepting Tiro) who maintained his ideological affiliation to Black Consciousness beyond the late 1970s. The others made shifts to support multiracial Charterism and eventually became UDF and ANC members. This political move has positioned them at or near the highest reaches of political power in post-apartheid South Africa, as one figure discussed here demonstrates especially well. Cyril Ramaphosa, who became president of the Turfloop off-campus branch of SASO in 1974, also endured periods of detention due to his student organizing in the mid- to late 1970s. He left Black Consciousness behind to organize under the multiracial umbrella of the ANC, and in the early 1980s he founded the National Union of Mineworkers, South Africa's largest trade union at the time. His work in the $\mathrm{UDF}$ and as an ANC negotiator positioned him near the core of party power in the late 1980s and early 1990s, but he was passed over for the position of Nelson Mandela's deputy president in favour of Thabo Mbeki in 1994. After more than a decade in the private sector, Ramaphosa returned to party politics in 2012, when he became Jacob Zuma's deputy president. In February 2018, after Zuma's removal from office by the ANC under a cloud of corruption allegations, Ramaphosa became the president of South Africa.

In this article, drawing on the concept of brain circulation, I have argued that the movement of these and other figures to and from different educational spaces in 1970s South Africa - township and village schools, and a Bantustan university - created a strong political system linked by what I have called nodes in a network. Following Saxenian, this is not a story of brain drain (of political ideas,

\footnotetext{
${ }^{25}$ Biography of Pandelani Jeremia Nefolovhodwe at <http://www.sahistory.org.za/people/pandelani-jeremia-nefolovhodwe>, accessed 10 April 2018.
} 
resources and skills) from the periphery to the core, but one of recirculation that supported development in both peripheral and central nodes.

The material presented here demonstrates the way in which the movement of these teachers - their migration as school students, to university at Turfloop, and, after various events that disrupted that campus and ended their university educations, to secondary school classrooms in townships on the Rand and in the Bantustans - shaped their politics and their teaching. Turfloop itself acted as a crucible where ideas of Black Consciousness were honed through the organization of SASO and the SRC. But part of the reason for its crucial role was the experiences from their early education that students brought with them to campus - of displacement, disruption and constraint. The very practices of moving, from school to school, from home to university and back (especially during periods when the university was forcibly closed - as in mid-1972) helped these student/teachers harness the destabilizing systems of apartheid education to propagate the politics of its undoing.

\section{Acknowledgements}

Versions of this article were presented at the Southern African Historical Society biennial conference in Johannesburg, 21-23 June 2017, and at the North Eastern Workshop on Southern Africa (NEWSA) in Burlington, Vermont, 6-8 October 2017. I am indebted to the discussants on each of my panels, Susanne Klausen and Wendy Urban Mead, for their thoughtful feedback, and to participants at both conferences, but particularly to Peter Alegi and Leslie Hadfield at NEWSA, for their stimulating comments, which shaped the writing and revision of this article.

\section{References}

This article relies on several archival collections held at the University of the Witwatersrand Historical Papers Archive (HPRA), notably (although not exclusively) their extensive collection on SASO (A2176) and their complete trial transcript of testimony from the court proceedings of State v. Sathasivan Cooper, Justice Edmund Lindane Myeza, Mosioua Gerard Patrick Lekota, Maitshe Nchaupe Aubrey Mokoape, Nkwenkwe Vincent Nkomo, Pandelani Jeremiah Nefolovhodwe, Gilbert Kaborane Sedibe, Strinivasa Rajoo Moodley, and Absolom Zitulele Cindi (collection A2021, elsewhere referred to as the 'SASO 9 trial transcript').

Badat, S. (1999) Black Student Politics: higher education and apartheid from SASO to SANSCO, 1968-1990. Pretoria: HSRC Press.

Biao, X. (2007) Global 'Body-shopping': an Indian labour system in the information technology industry. Princeton NJ: Princeton University Press.

Biko, S. (2017) I Write What I Like. 40th anniversary edition. Johannesburg: Picador Africa.

Brown, J. (2016) The Road to Soweto: resistance and the uprising of 16 June 1976. Oxford: James Currey.

Butler, A. (2007) Cyril Ramaphosa. Johannesburg: Jacana. 
Chikane, F. (1988) No Life of My Own: an autobiography. Johannesburg: Picador Africa.

Chikane, F. (2012) Eight Days in September: the removal of Thabo Mbeki. Johannesburg: Picador Africa.

Delius, P. (1996) A Lion amongst the Cattle: reconstruction and resistance in the Northern Transvaal. Oxford: James Currey.

Dikobo, K. (2012) 'Esau Mokhethi reburial speech', AZAPO, 29 March, <http:/l azapo.org.za/esau-mokhethi-reburial-speech/>, accessed 13 November 2018.

Diseko, N. (1992) 'The origins and development of the South African Students' Movement (SASM): 1968-1976', Journal of Southern African Studies 18 (1): 40-62.

Everatt, D. (2010) The Origins of Nonracialism: white opposition to apartheid in the 1950s. Johannesburg: Wits University Press.

Frederikse, J. (1990) The Unbreakable Thread: nonracialism in South Africa. Bloomington IN: Indiana University Press.

Glaser, C. (2000) Bo-Tsotsi: the youth gangs of Soweto, 1935-1976. Oxford: James Currey.

Glaser, C. (2015) 'Soweto's islands of learning: Morris Isaacson and Orlando High Schools under Bantu Education, 1958-1975', Journal of Southern African Studies 41 (1): 159-71.

Heffernan, A. (2014) 'A history of youth politics in Limpopo, 1967-2003'. DPhil thesis, University of Oxford.

Heffernan, A. (2015) 'Black Consciousness's lost leader: Abraham Tiro, the University of the North, and the seeds of South Africa's student movement in the 1970s', Journal of Southern African Studies 41 (1): 173-86.

Heffernan, A. (2016) 'Blurred lines and ideological divisions in South African youth politics', African Affairs 115 (461): 664-87.

Hirson, B. (2016 [1979]) Year of Fire, Year of Ash: the Soweto schoolchildren's revolt that shook apartheid. London: Zed Books.

Hyslop, J. (1989) 'A destruction coming in: Bantu Education in response to social crisis'. Paper presented at University of the Witwatersrand African Studies Institute seminar.

Hyslop, J. (1999) The Classroom Struggle: policy and resistance in South Africa, 1940-1990. Durban: University of Natal Press.

Lekgoathi, S. (2016) 'Youth politics and rural rebellion in Zebediela and other parts of the "Homeland" of Lebowa, 1976-1977' in A. Heffernan and N. Nieftagodien (eds), Students Must Rise: youth struggle in South Africa before and beyond Soweto '76. Johannesburg: Wits University Press.

Lekgoathi, S. (2017) 'The 1976 Soweto students' uprising and its aftermath in parts of the Northern Transvaal' in South African Democracy Education Trust, The Road to Democracy in South Africa. Vol. 7: New perspectives, commemorations and memorialization. Pretoria: UNISA Press.

Lissoni, A. (2016) 'Student organization in Lehurutshe and the impact of Onkgopotse Abram Tiro' in A. Heffernan and N. Nieftagodien (eds), Students Must Rise: youth struggle in South Africa before and beyond Soweto '76. Johannesburg: Wits University Press.

Magaziner, D. (2010) The Law and the Prophets: Black Consciousness in South Africa, 1968-1977. Athens OH: Ohio University Press. 
Massey, D. (2010) Under Protest: the rise of student resistance at the University of Fort Hare. Pretoria: UNISA Press.

Mkhabela, S. (2001) Open Earth and Black Roses: remembering 16 June 1976. Johannesburg: Skotaville Press.

Moloi, T. (2015) Place of Thorns: black political protest in Kroonstad since 1976. Johannesburg: Wits University Press.

Motapanyane, T. (1977) 'How June 16 demo was planned', Sechaba 11 (2): 2.

Murphy, O. M. (2012) 'Race, violence, and nation: African nationalism and popular politics in South Africa's Eastern Cape, 1948-1970'. DPhil thesis, University of Oxford.

Ndlovu, S. M. (2017) 'Cultural imperialism, language, and the ideological struggle inside the Soweto classrooms' in South African Democracy Education Trust, The Road to Democracy in South Africa. Vol. 7: New perspectives, commemorations and memorialization. Pretoria: UNISA Press.

Nieftagodien, N. (2015) The Soweto Uprising. Athens OH: Ohio University Press.

Saxenian, A. (2005) 'From brain drain to brain circulation: transnational communities and regional upgrading in India and China', Studies in Comparative International Development 40 (2): 35-61.

Saxenian, A. (2006) The New Argonauts: regional advantage in a global economy. Cambridge MA: Harvard University Press.

Schenck, M. C. (2019) 'Negotiating the German Democratic Republic: Angolan student migration during the Cold War, 1976-90', Africa 89 (S1): S144-S166.

Tiro, O. A. R. (1972) 'Graduation speech for the University of the North', South African History Online, 29 April, <http://www.sahistory.org.za/article/graduation-speech-onkgopotse-tiro-university-north-29-april-1972>, accessed 13 November 2018.

Todaro, M. P. (1977) Economic Development in the Third World: an introduction to problems and policies in global perspective. London: Longman.

White, C. (1997) From Despair to Hope: the Turfloop experience. Sovenga: UNIN Press.

\begin{abstract}
The movement of school teachers to primary and secondary schools around South Africa and its Bantustans in the early and mid-1970s was an intentional part of the project of propagating Black Consciousness to school learners during this period. The movement of these educators played a key role in their ability to spread Black Consciousness philosophy, and in the political forms and methods they chose in teaching it. These were shaped by their own political conscientization and training in ethnically segregated colleges, but also in large part by the social realities of the areas to which they moved. Their efforts not only laid the foundation for Black Consciousness organization in communities across South Africa, they also influenced student and youth mechanisms for political action beyond the scope of Black Consciousness politics. This article explores three case studies of teachers who studied at the University of the North (Turfloop) and their trajectories after leaving university. All of these teachers moved to Turfloop as students, and then away from it thereafter. The article argues that this pattern of movement, which was a direct result of apartheid restrictions on where black South Africans
\end{abstract}


could live, study and work, shaped the knowledge they transmitted in their classrooms, and thus influenced the political consciousness of a new generation.

\section{Résumé}

Le mouvement enseignant dans les écoles primaires et secondaires en Afrique du Sud et ses bantoustans dans la première moitié des années 1970 était un élément délibéré du projet de propagation de la Conscience noire (Black Consciousness, BC) aux écoliers pendant cette période. Le mouvement de ces éducateurs a joué un rôle clé dans leur aptitude à disséminer la philosophie BC, et dans les formes et méthodes politiques qu'ils ont choisies pour l'enseigner. Ces dernières étaient influencées par leur propre conscientisation politique et formation dans des établissements ethniquement ségrégués, mais aussi pour une large part par les réalités sociales des régions dans lesquelles ils étaient mutés. Leurs efforts ont jeté les bases de l'organisation BC dans les communautés sud-africaines, mais ils ont aussi influencé les mécanismes d'action politique parmi les étudiants et les jeunes au-delà du champ de la politique BC. Cet article explore trois études de cas d'enseignants qui ont étudié à l'Université du Nord (Turfloop) et leurs parcours postuniversitaire. Tous ces étudiants sont allés à Turfloop pour y étudier et en sont ensuite partis. L'article soutient que ce schéma de mouvement, qui était une conséquence directe des restrictions imposées par l'apartheid quant aux lieux où les Sud-Africains noirs pouvaient vivre, étudier et travailler, a influencé les connaissances qu'ils transmettaient dans leurs classes et par là-même la conscience politique d'une nouvelle génération. 